\title{
Reproductive biology of the swimming crab Achelous spinimanus (Decapoda, Portunoidea): a potential fishing resource
}

\author{
Aline N. Sousa' (1), Veronica P. Bernardes ${ }^{1}$ (D), Camila H. Bernardo' (1), Fabiano G. Taddei ${ }^{1,2}$ (D), \\ Gustavo M. Teixeira ${ }^{1,3}$ (D) , Rogério C. Costa ${ }^{1,4}$ (D) , Adilson Fransozo ${ }^{1}$ (i)
}

\begin{abstract}
1. Núcleo de Estudos em Biologia, Ecologia e Cultivo de Crustáceos (NEBECC), Departamento de Zoologia, Instituto de Biociências, Universidade Estadual Paulista (UNESP), Câmpus de Botucatu, Rua Prof. Dr Antonio Celso Wagner Zanin, s/n, Distrito de Rubião Junior, Botucatu, SP, Brasil.

(alinensousa1@gmail.com; vebernardes@gmail.com; caah.hipolito05@gmail.com; fgtaddei@hotmail.com; rccosta@fc.unesp.br; fransozo@ibb.unesp.br) 2. Laboratório de Estudos de Crustáceos Amazônicos (LECAM), Universidade do Estado do Amazonas (UEA), Parintins, AM, Brasil.

3. Universidade Estadual de Londrina (UEL), Câmpus Universitário, Rod. Celso Garcia Cid, Km 380, s/n, Londrina, PR, Brasil. (gmteixeira@uel.br)

4. Laboratório de Biologia de Camarões Marinhos e de Água Doce (LABCAM), Faculdade de Ciências, Universidade Estadual Paulista (UNESP),

Câmpus de Bauru, SP, Brasil.
\end{abstract}

ABSTRACT. This study describes the reproductive and recruitment patterns of the swimming crab Achelous spinimanus (Latreille, 1819) in the Ubatuba region of the northern coast of São Paulo, Brazil. Crabs were captured monthly from January 1998 to December 1999 in 18 sites located in three bays (Ubatumirim, Ubatuba, and Mar Virado), using a commercial fishing boat. In each sampling area, bottom temperature, salinity, and organic matter content were recorded. A total of 1,911 individuals were captured: 350 adult males, 475 non-ovigerous adult females, 584 adult ovigerous females, and 502 immature individuals. Reproductive females were more abundant in deeper areas; this migration might be a strategy to improve larval dispersion and survival. Ovigerous females were found year-round, indicating a continuous reproduction, and their abundance was positively correlated with temperature. During the 2-year survey, crabs with all gonadal development stages were found. We can infer that this region provides suitable resources for the development of $A$. spinimanus.

KEYWORDS. Fishing, organic matter, recruitment, temperature, Ubatuba.

RESUMO. Biologia reprodutiva do siri Achelous spinimanus (Decapoda, Portunoidea): um recurso pesqueiro em potencial. Este estudo descreveu os padrões reprodutivos e de recrutamento do siri Achelous spinimanus (Latreille, 1819) na região de Ubatuba, litoral norte de São Paulo, Brasil. Os siris foram coletados mensalmente, de janeiro de 1998 a dezembro de 1999, em 18 locais em três enseadas (Ubatumirim, Ubatuba e Mar Virado), utilizando um barco de pesca comercial. Em cada área de amostragem foram registrados a temperatura de fundo, salinidade e teor de matéria orgânica. Um total de 1.911 indivíduos foram coletados: 350 machos adultos, 475 fêmeas adultas não ovígeras, 584 fêmeas adultas ovígeras e 502 jovens. As fêmeas reprodutivas foram mais abundantes em áreas profundas; essa migração pode ser uma estratégia para melhorar a dispersão e a sobrevivência das larvas. As fêmeas ovígeras foram encontradas durante todo o ano, indicando uma reprodução contínua, com sua abundância positivamente correlacionada à temperatura. Durante a pesquisa de dois anos, foram encontrados caranguejos em todos os estágios de desenvolvimento gonadal. Podemos inferir que a região de Ubatuba fornece recursos adequados para o estabelecimento e desenvolvimento de $A$. spinimanus.

PALAVRAS-CHAVE. Matéria orgânica, pesca, recrutamento, temperatura, Ubatuba.

Food availability is considered one of the most important factors influencing the somatic growth and reproduction of adults, larvae, and juveniles of benthic marine invertebrates (COBO \& Fransozo, 2003). However, food is not the only modulator, it is one of many variables controlling the reproductive period. These variables are classified as proximal or ultimate factors. Proximal factors (temperature, salinity, and other environmental variables) would influence either the beginning or the ending of incubation and spawning (MORRITT \& STEVENSON, 1993). Ultimate factors (selective pressures) would determine the reproductive period, which usually corresponds to the period of higher planktonic food availability (LEIFSSON, 1998).
The latitudinal variation is one of the factors influencing the duration of the reproductive period (TEROSSI et al., 2010). For most decapod species in tropical regions, two types of reproduction have been recorded: a continuous reproduction occurring year-round, e.g. Arenaeus cribarius Lamarck, 1818 were obtained from Fortaleza Bay and Ubatuba Bay (PinHeIRo \& Fransozo, 2002) and Hepatus pudibundus (Herbst, 1785) in three bays having distinct physiographical features (Lima et al., 2014), and a continuous reproduction with peaks in some periods e.g, ovigerous females of Liocarcinus puber Manning \& Holthuis, 1981 from the Gower Peninsula were recorded throughout the year, with highest proportions between February and April (CHOY, 1988) 
and Achelous spinicarpus (Stimpson, 1871) in Ubatuba region shows continuous reproduction with peaks ovigerous females occurred mostly during spring and summer seasons (SILVA et al., 2017). In temperate regions, a seasonal reproduction is often seen, e.g. reproduction in north-temperate littoral populations of Pagurus bernhardus (Linnaeus, 1758) is seasonal and asynchronous, occurring during the months of November to May in response to cold water temperatures and reduced photoperiods (LANCASTER, 1990), and TEROSSI et al. (2010) noticed Pagurus exilis (Benedict, 1892) reproduction in Brazil occurs year round, with peaks in the fall and winter seasons; in Argentina reproduction occurs only in spring and summer. However, BAUER (1992) stated that there is no general model to explain the duration of the reproductive period of marine crustaceans. Different species have distinct phylogenetic histories, peculiar reproductive capacities, and restrictions imposed by body size. Therefore, in similar latitudes, there are several variations in habitat features and in other biotic and abiotic parameters that also influence the reproductive patterns.

The knowledge on the reproductive biology of decapods is crucial to understand their life cycles (ANDRADE et al., 2015a). This is especially important in the case of populations that are becoming new fishing targets, such as some Portunidae species. A large part of the benthic fauna associated is formed by brachyuran crustaceans, particularly Portunidae, this dominance may have contributed to the popularization of swimming-crab fisheries, making this one of the oldest fishing activities along the Brazilian coast (SEverino-Rodrigues et al., 2018). Presently several communities survive from the commercialization of these crabs (BARRETO et al., 2006).

Despite the considerable amount of available information on the reproductive patterns of A. spinimanus, additional data are needed due to the increasing commercial interest in this species. The stocks' decline of more profitable species, such as Farfantepenaeus brasiliensis (Latreille, 1817), F. paulensis (Perez-Farfante, 1967), Xiphopenaeus kroyeri (Heller, 1862) (D'INCAO et al., 2002) and Litopenaeus schmitti (Burkenroad, 1936), has turned A. spinimanus into a new fishing target. Exploitation of the meat and byproducts of $A$. spinimanus for economic uses is increasing in Brazil, as also in other countries since 1999 (FAO-GLOBEFISH, 2007). The size and taste of this swimming crab makes it suitable for human consumption (SANTOS et al., 1995; BRANCO et al., 2002; Sousa et al., 2018).

Several studies reported the reproductive patterns of Achelous spinimanus (Latreille, 1819) in Brazil. Santos \& Negreiros-Fransozo (1999) recorded a continuous reproduction in Ubatuba. They also showed that the reproductive peaks were not directly related to temperature, but to the presence of suitable conditions for larval development. On the other hand, in a resurgence area in the Southeast of Brazil, A. spinimanus showed a seasonal reproductive period ANDRADE et al. (2017). Its estimated fecundity ranges from 188,065 to 682,992 eggs; this relatively high fecundity is a strategy shown by species with a high larval mortality (SAntos \& Negreiros-Fransozo, 1997). DE-CARLi et al. (2016) studied individuals of A. spinimanus from fishery landings in the coast of São Paulo and concluded that they were using the area to reproduce. Ripoli et al. (2007) suggested that $A$. spinimanus in Frade Island (Espírito Santo) may be living in the area for recruitment, feeding and reproduction, due to some evidences such as predominance of juvenile individuals, abundant feeding resources and occurrence of ovigerous females.

This study aimed to elucidate the reproductive biology and recruitment of $A$. spinimanus in the Ubatuba region of the northern coast of São Paulo, Brazil, focusing on the temporal and spatial distribution of reproductive females and juveniles. We also investigated the relationships between juveniles and reproductive females with the following environmental parameters: bottom water temperature and salinity and organic matter content.

\section{MATERIAL AND METHODS}

Study area. Ubatuba is located in the northern coast of São Paulo State, Brazil. This region has a unique geological conformation and is known for its very irregular coast (AB'SABER, 1955). Ubatuba is influenced by three water masses: Coastal Water $\left(\mathrm{CW}\right.$ : temperature $\geq 20^{\circ} \mathrm{C}$; salinity $\leq 36$ ), Tropical Water (TW: temperature $\geq 20^{\circ} \mathrm{C}$; salinity $\geq$ 36), and South Atlantic Central Water (SACW: temperature $\leq 18^{\circ} \mathrm{C}$; salinity $\left.\leq 36\right)($ CASTRo-Filho et al., 1987). During late spring and early summer, the SACW penetrates into the coast's bottom layer and forms a thermocline over the inner shelf at depths of $10-15$ m (CASTRO-Filho et al., 1987). During winter, the SACW retreats to the shelf break and is replaced by the $\mathrm{CW}$, resulting in the absence of temperature stratification over the inner shelf during winter (PIRES, 1992).

Since October 8, 2008, UBM, UBA and MV are parts of a Marine Protection Area (MPA) (APA Marinha do LitoralCunhambebe Sector) created by the Ministry of Environment (decree number 53.525). This MPA was established to ensure the conservation and sustainable use of marine resources. Fishing is only permitted for the subsistence of traditional communities, by amateurs, and as a leisure activity, thus, commercial fishing is not allowed. These restrictions aim to protect the area and promote the rational use of its natural resources, ensuring the region's sustainable development.

Sampling. We captured the swimming crabs monthly from January 1998 through December 1999. In each bay, six sampling stations were established: three stations were located in areas sheltered from the waves $(5,7.5$ and $10 \mathrm{~m}$ deep), and three were located in exposed areas $(10,15$ and $20 \mathrm{~m}$ deep) (Fig. 1). The stations (except the 7.5 and $10 \mathrm{~m}$ depths) were positioned along transects set parallel to the coastline. These stations were selected according to the following characteristics: their position relative to the bay's mouth, the presence of rocky shores or beaches along the bay's perimeter, freshwater inflow, proximity to offshore water, depth, and sediment texture. Trawling was conducted on a commercial shrimp fishing boat outfitted with double-rig 


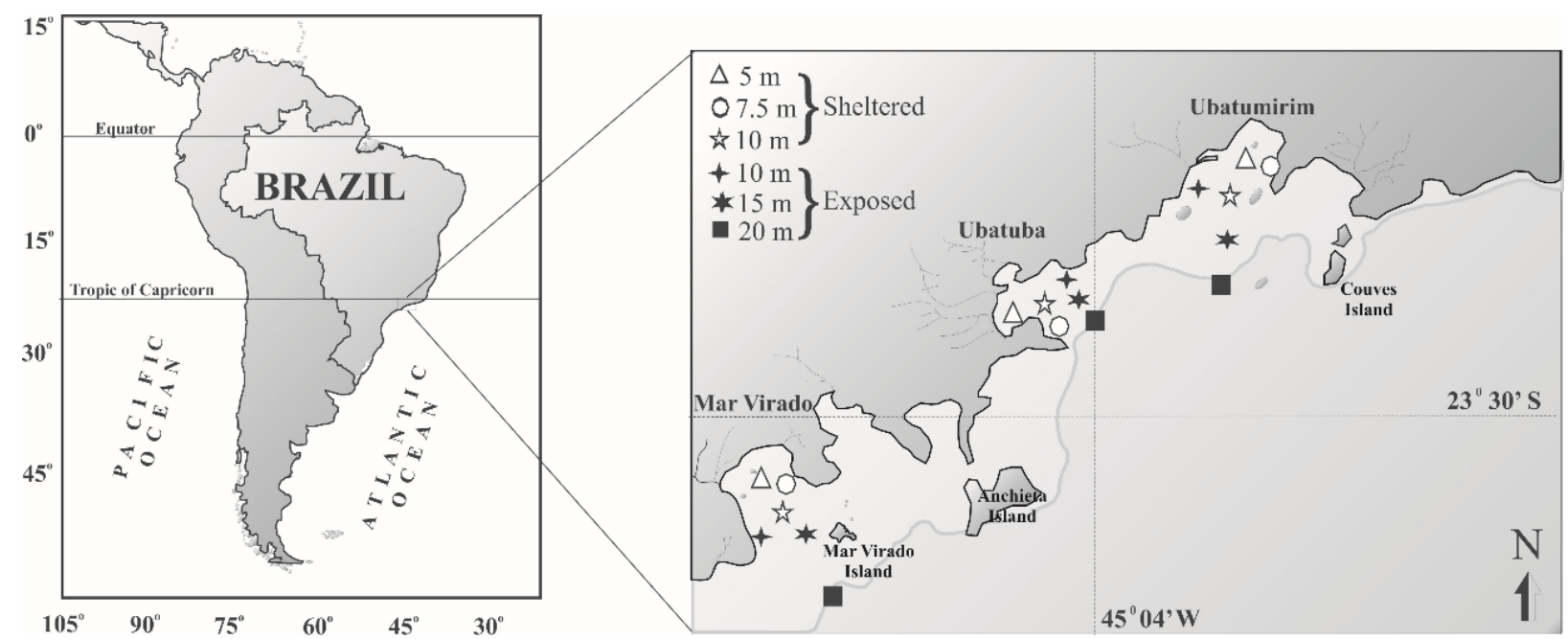

Fig. 1. Map of the Ubatuba region, in the northeastern coast of São Paulo state, Brazil, showing the three bays (Ubatumirim, Ubatuba and Mar Virado), and their respective sampling stations. Font: adapted from ANDRADE et al. (2014).

nets. Each area (18 sites) was trawled monthly ( 24 months) for $30 \mathrm{~min}$ and covered a total of $18,000 \mathrm{~m}^{2}$ per trawl.

At each sampling occasion, the following parameters were recorded: bottom (BT) and surface (ST) water temperature $\left({ }^{\circ} \mathrm{C}\right)$, bottom salinity $(\mathrm{BS})$, depth $(\mathrm{m})$, and percentage organic matter. Water samples were taken with a Nansen bottle to obtain salinity and temperature with an optical refractometer and a thermometer, respectively. Depth was measured with an echobathymeter coupled to a Global Positioning System (GPS). Sediment samples for the determination of organic matter content were taken with a Van Veen grab. Immediately after collection, we put the sediment samples into labelled plastic bags and froze them to minimize the organic matter decomposition until further analyses.

To determine the sediment organic matter content, we put $10 \mathrm{~g}$ subsamples in porcelain containers, previously labelled and weighed. They were oven-dried $\left(500^{\circ} \mathrm{C}\right.$ for 3 hours) and weighed. The difference between the initial and final weight indicated the organic matter content of each sampling station, what was later converted into percentages (HeIRI et al., 2001).

Biological data. Achelous spinimanus individuals were identified according to MeLo (1996) and sexed upon inspecting the abdominal morphology (triangular in males and rounded in females) and pleopod number (two pairs in males and four pairs in females). Individuals were categorized into demographic groups: adult males, non-ovigerous adult females, ovigerous females, and juveniles (with the abdomen adhering to the thoracic esternites). Four stages of gonadal development were established for males and females based on the gonad's size, shape, and color: 1) IM: undifferentiated gonads; 2) RU: rudimentary (males: uncolored filamentous vas deferens; females: whitish, thin filamentous ovary); 3) ED: developing (males: white gonads of small volume, being smaller than the hepatopancreas; females: beginning of maturation, small yellow ovaries); 4) DE: developed (males: largest gonadal development size, white gonads; females: bright yellow ovaries filling almost all thoracic cavity) (SANTos \& Negreiros-Fransozo, 1999).

Data analyses. A contingency table with the abundance of demographic groups per season was created using a correspondence analysis (CA). To allow a clear visualization of the correlation/abundance of each demographic group per bathymetric zone and season, each datapoint was plotted proportionally to the abundance in the contingency table. A Pearson's chi-square test with a simulated p-value was used to test the significance of the correlations (based on 2,000 simulations) (NenAdic \& Greenacre, 2007).

The reproductive period was estimated based on the monthly frequency of ovigerous females in relation to the total number of females. Similarly, the recruitment was expressed by the monthly frequency of juveniles in relation to the total number of individuals (NENADIC \& GREENACRE, 2007).

The relationship between the abundance of ovigerous females and juveniles and the environmental parameters (temperature, bottom salinity, and mean organic matter content) was evaluated with a Redundancy Analysis (RDA). The RDA is a multivariate statistical test that measures how strong is the association between groups of variables. The environmental parameters were included in the first group, and the abundance of ovigerous females (OF) and juveniles (J), in the second group. The RDA generates final coordination scores indicating the linear relationship between explanatory and response variables. The RDA produces final coordination scores that summarize the linear relationship between the explanatory and response variables. Only environmental variables with scores higher than 0.4 and lower than -0.4 were considered as biologically significant 
(RAKOCINSKi et al., 1996). The CA and RDA were performed using the "ca" and "Vegan" packages (OKSANEN et al., 2013; R Development Core Team, 2013).

\section{RESULTS}

The largest differences between surface and bottom temperatures occurred in summer and spring in both years (Fig. 2). In deeper sites (10, 15, and $20 \mathrm{~m}$ ) there was a large difference between the mean bottom and surface temperatures (thermocline) (Fig. 2). Three water masses were recorded during our survey, which are typical of Ubatuba: Continental Waters $\left(\mathrm{CA}\right.$; temperature $\geq 20^{\circ} \mathrm{C}$, salinity $\leq$ 36), South Atlantic Central Waters (SACW; temperature $\leq$ $18^{\circ} \mathrm{C}$, salinity $\leq 36$ ), and Tropical Waters (TW; temperature $\geq 20^{\circ} \mathrm{C}$, salinity $\geq 36$ ) (Fig. 3). The sites near the coast had the highest organic matter content, whereas the site $20 \mathrm{~m}$ deep had the lowest (3.3\%).

In total, 1,911 individuals of $A$. spinimanus were captured: 350 adult males, 475 non-ovigerous adult females, 584 adult ovigerous females, and 502 immature individuals. Most individuals, either juveniles or adults, were found at the $7.5 \mathrm{~m}$ of depth (Tab. I). However, only adults (males and females, mainly ovigerous) had a high association with deeper areas, especially at $20 \mathrm{~m}$ (Fig. 4).

Both the reproductive and recruitment periods were continuous (Fig. 5). Males and females with developed gonads were found in all seasons, indicating an intense and constant reproductive activity of both sexes. Even though all demographic groups were found during the entire survey, the temporal distribution, based on the CA analysis (Fig. 6), indicated a relationship between ovigerous females and spring, and between immature individuals and summer and autumn.
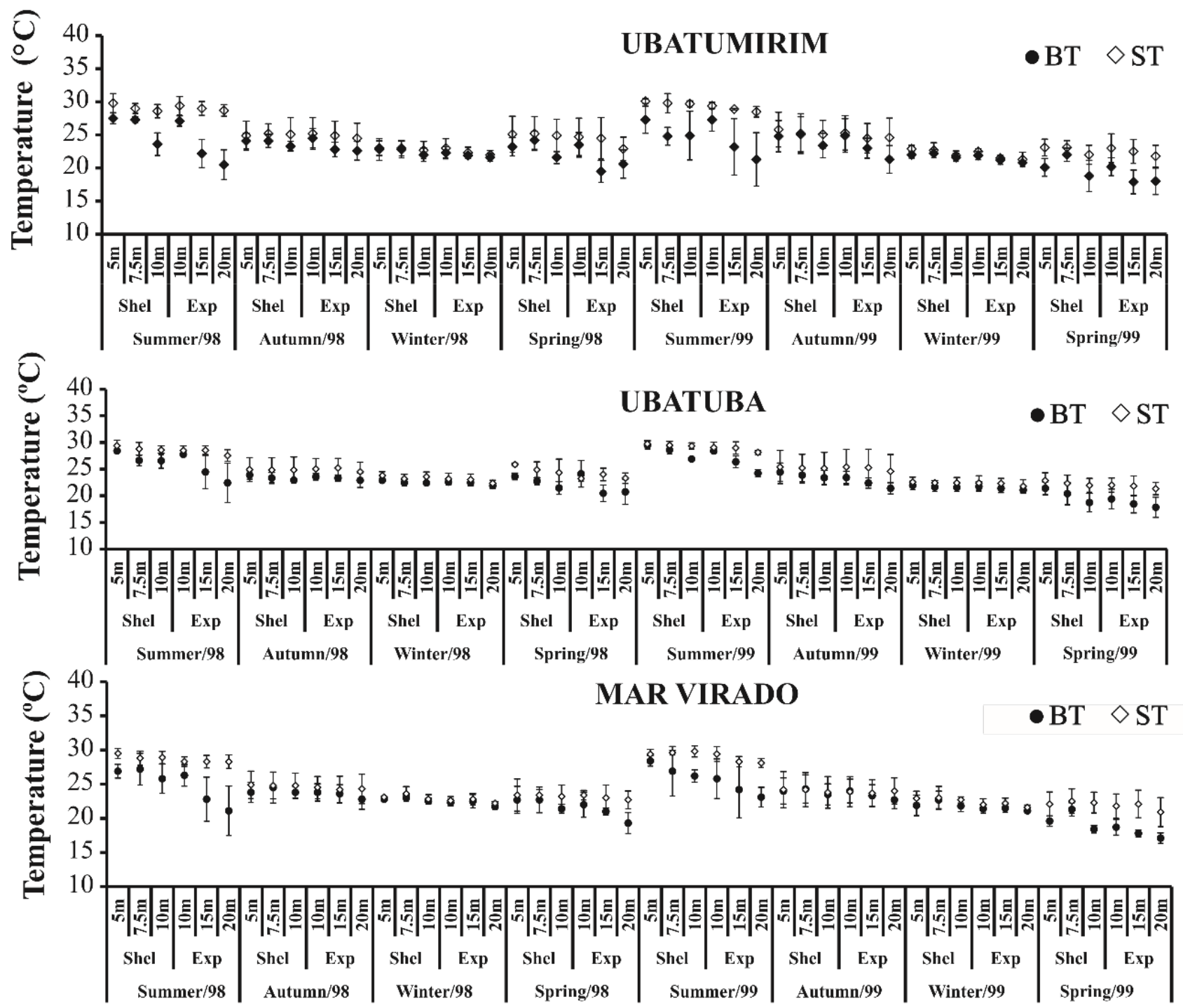

Fig. 2. Bottom and surface temperature (BT and ST, respectively), seasonal variation in each sampling stations and areas $($ Shel $=s h e l t e r e d$ and Exp $=$ exposed) from 1998 to 1999. 

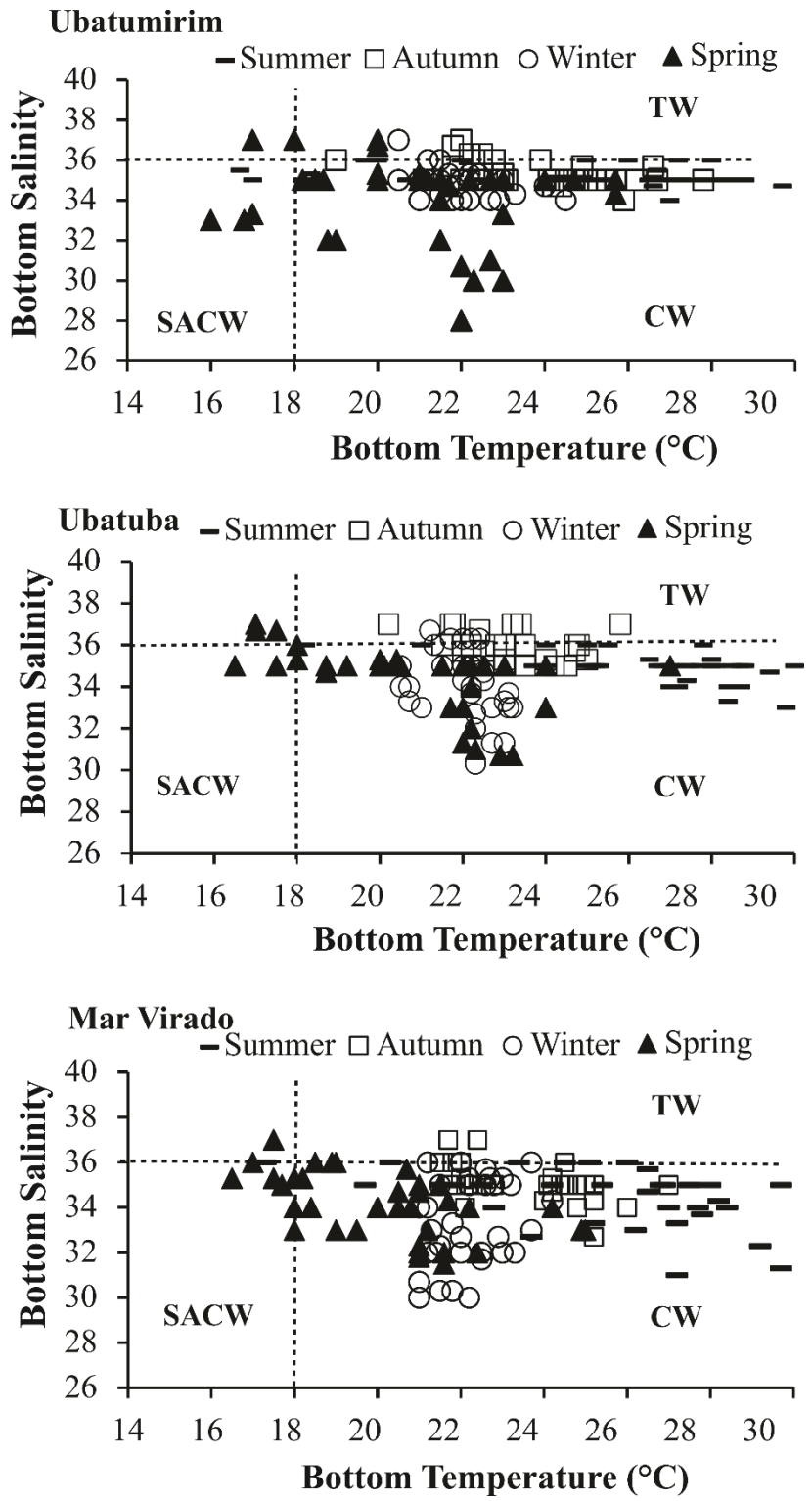

Fig. 3. Diagram showing the seasonal variation of water temperature and salinity from January 1998 to December 1999, in three bays (Ubatumirim, Ubatuba and Mar Virado), from the São Paulo state, southeastern coast of Brazil (CW, Coastal Water; TW, Tropical Water; SACW, South Atlantic Central Water).

Tab. I. Distribution of males (M) and females (F) of Achelous spinimanus (Latreille, 1819) according to gonadal development stage in the Ubatuba region (OF, ovigerous females; DE, developed gonads; ED, developing gonads; RU, rudimentary gonads; IM, immatures).

\begin{tabular}{|c|c|c|c|c|c|c|c|c|}
\hline & & \multicolumn{6}{|c|}{ Sampling stations } & \multirow{3}{*}{ Total } \\
\hline & & \multicolumn{3}{|c|}{ Sheltered area } & \multicolumn{3}{|c|}{ Exposed area } & \\
\hline & & $5 \mathrm{~m}$ & $7.5 \mathrm{~m}$ & $10 \mathrm{~m}$ & $10 \mathrm{~m}$ & $15 \mathrm{~m}$ & $20 \mathrm{~m}$ & \\
\hline \multirow[t]{5}{*}{ Females } & IM & 4 & 187 & 7 & 3 & 23 & 20 & 244 \\
\hline & RU & 0 & 134 & 0 & 1 & 12 & 41 & 188 \\
\hline & ED & 1 & 40 & 0 & 2 & 5 & 7 & 55 \\
\hline & $\mathrm{DE}$ & 0 & 153 & 2 & 0 & 24 & 53 & 232 \\
\hline & FO & 3 & 379 & 5 & 5 & 52 & 140 & 584 \\
\hline \multirow[t]{4}{*}{ Males } & $\mathrm{IM}$ & 6 & 191 & 6 & 4 & 22 & 29 & 258 \\
\hline & $\mathrm{RU}$ & 1 & 72 & 0 & 0 & 5 & 16 & 94 \\
\hline & $\mathrm{ED}$ & 0 & 75 & 1 & 3 & 9 & 20 & 108 \\
\hline & $\mathrm{DE}$ & 1 & 88 & 0 & 0 & 11 & 48 & 148 \\
\hline Total & & 16 & 1,319 & 21 & 18 & 163 & 374 & 1,911 \\
\hline
\end{tabular}






Fig. 4. Achelous spinimanus (Latreille, 1819). Correspondence Analysis (CA) of the abundance of demographic groups in the sampling stations sampled in the Ubatuba region. At the bottom the statistical summary of Pearson's chi-squared test for randomness of the observed association (J, juveniles; AM, adult males; $\mathrm{AF}$, adult females; OF, ovigerous females; exp, exposed; shel, sheltered).
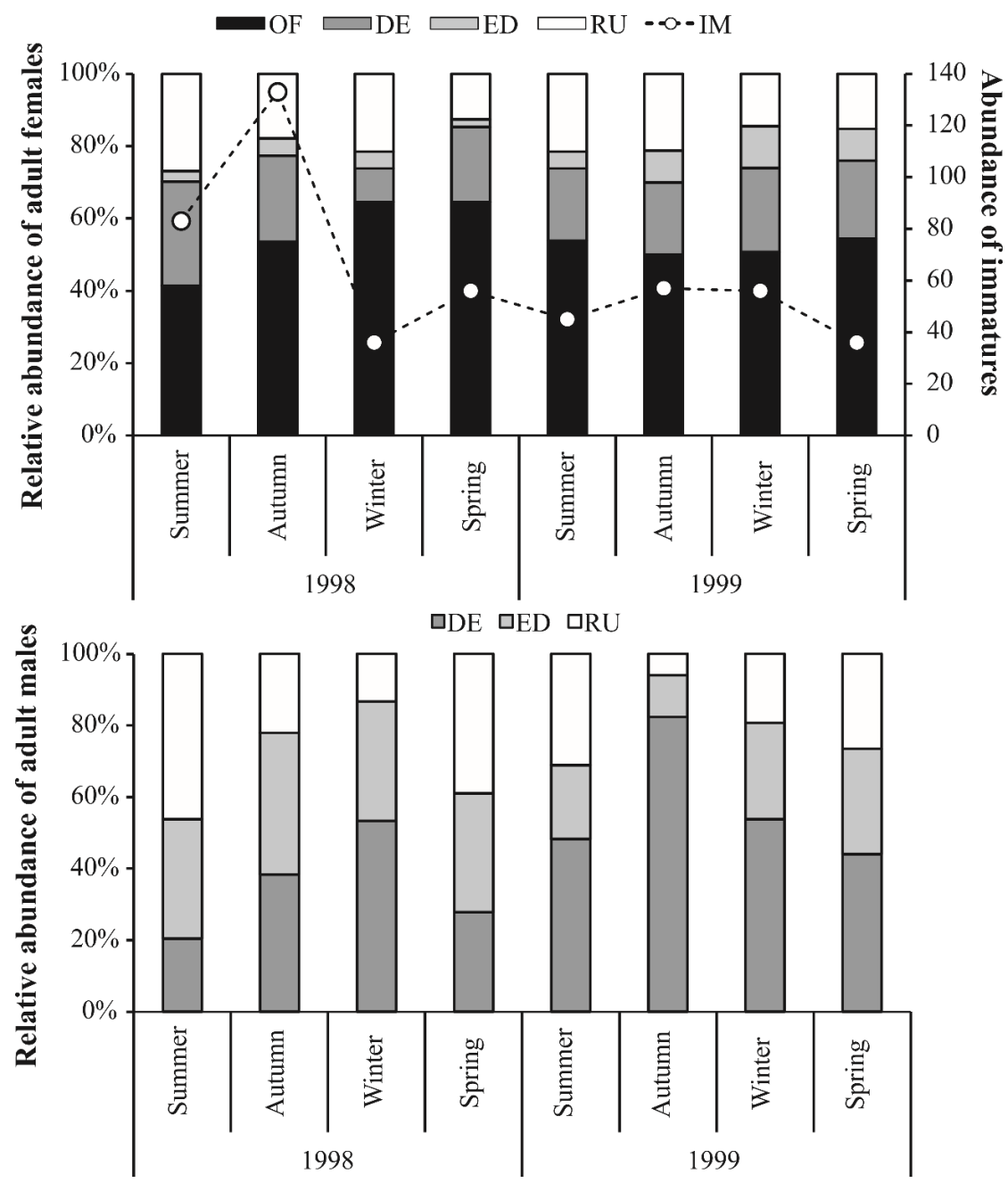

Fig. 5. Achelous spinimanus (Latreille, 1819). Seasonal variation in the proportion of adult females and adult males in different gonadal stages in the Ubatuba region (OF, ovigerous females; DE, developed gonads; ED, developing gonads; RU, rudimentary gonads; IM, immatures). 
There was a significant correlation between three abiotic parameters (temperature, bottom salinity, and mean organic matter content) and the abundance of ovigerous females and juveniles (Tab. II). According to the RDA axis 1 , which explained $75 \%$ of the variance, low bottom temperatures favored the abundance of ovigerous females, or at low temperatures there is an increased abundance of ovigerous females. The abundance of juveniles was associated with higher values of sediment organic matter contents and bottom temperature, sites with large amounts of organic matter and high temperatures probably have a higher number of juveniles.

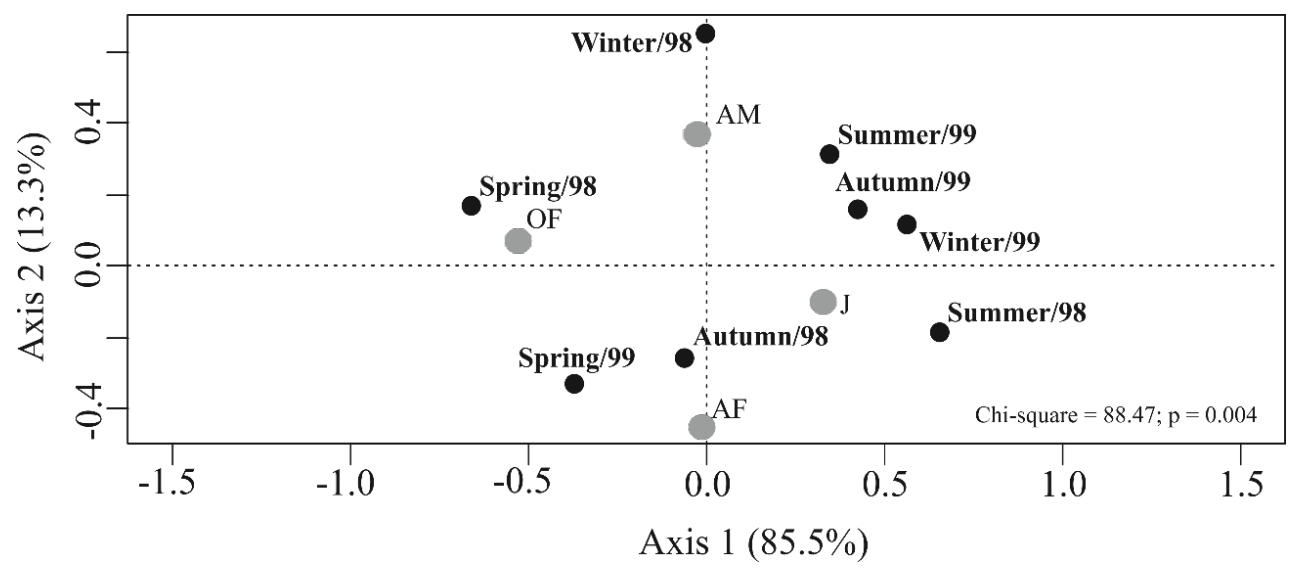

Fig. 6. Achelous spinimanus (Latreille, 1819). Correspondence Analysis (CA) of the abundance of demographic groups in the seasons in 1998 and 1999 sampled in the Ubatuba region (J, juveniles; AM, adult males; AF, adult females; OF, ovigerous females).

Tab. II. Achelous spinimanus (Latreille, 1819). Results from the redundancy analysis (RDA): ordination of the first two canonical axes, with environmental variable data and demographic categories' abundance in the Ubatuba region. Coefficients greater than or equal to +0.4 or lower than or equal to -0.4 were considered ecologically relevant (RAKOcINSKI et al., 1996) and are shown in bold.

\begin{tabular}{|c|c|c|}
\hline & Axis 1 & Axis 2 \\
\hline Eigenvalue & 0.03 & 0.01 \\
\hline$\%$ of variance & 0.75 & 0.25 \\
\hline \multicolumn{3}{|l|}{ Demographic categories } \\
\hline Juveniles & -0.66 & 0.19 \\
\hline Ovigerous females & 0.33 & 0.38 \\
\hline \multicolumn{3}{|l|}{ Environmental variables } \\
\hline Bottom temperature & -0.92 & -0.38 \\
\hline Bottom salinity & 0.23 & -0.50 \\
\hline Organic matter & -0.51 & 0.76 \\
\hline
\end{tabular}

\section{DISCUSSION}

Although ovigerous females of A. spinimanus were found at the $7.5 \mathrm{~m}$ deep sites, they were the most abundant demographic group in the deeper sites $(15$ and $20 \mathrm{~m})$. This behavior which is consistent with the patterns proposed for crustaceans with planktotrophic larval stages. Because to the improvement of larval dispersion and survival, since environmental conditions are more stable at higher depths and thus the larvae suffer less physiological stress (ABELLÓ, 1989). Also, in deeper regions the larval dispersal is facilitated by oceanic currents and the predation pressure is less intense (ANDRADE et al., 2014).
BERNARDES et al. (2019) suggested that ovigerous females of $H$. pudibundus are usually found in deeper sites because from the coast have higher salinity, which favors the embryo development during incubation. The differential occupation by different demographic groups has been previously recorded in other species. For instance, immature individuals of $C$. ornatus were more abundant in shallow waters near the coast (ANDRADE et al., 2014). This habitat choice might be related to a higher food and shelter availability since shallow waters are more protected and have higher organic matter contents (ANDRADE et al., 2014). These authors suggested that ovigerous females move away from the coast because their larvae would fluctuate more easily at 
higher salinities. A differential occupation pattern was also seen in a population of $A$. spinimanus in Fortaleza Bay, where immature individuals were more abundant in shallow areas (4 m of depth) (SANTOS et al., 1995). The authors suggested that the higher productivity of shallow waters would lead to higher growth rates and favor the establishment of immature individuals. NegreIros-Fransozo et al. (1991), in a study in the Fortaleza Bay, evidenced that the sample area with the highest content of organic matter was the most appropriate place for the development and proliferation of organisms. Besides that, Fransozo et al. (1992) that organic matter content can modulate the occurrence and distribution of the Brachyura.

It is worth mentioning that the highest abundance of all demographic groups was recorded at $7.5 \mathrm{~m}$, which is located within an area naturally excluded from fisheries. The absence of fishing might have contributed to this higher abundance of swimming crabs. Areas less impacted by fisheries have their habitat complexity preserved, which favors the establishment of new individuals (KAISER et al., 2002). According to Fransozo et al. (2016), the fishing activity is predatory and disturbs the benthic communities, since it lacks a defined target and mixes the sea bed, thus displacing or removing organisms from their habitats.

Our results indicate that the studied population has a continuous reproduction, since ovigerous females were found year-round. Extensive reproductive periods are characterized by several spawning events throughout the year (GIESE, 1959). A continuous reproduction is a common feature of tropical and subtropical marine brachyurans.

However, there are records of A. spinimanus reproducing seasonally, during summer and autumn, in Macaé, Rio de Janeiro (ANDRADE et al., 2017). This record corroborates the data from the North Hemisphere where ovigerous females of this species were found only in the warmer months (DUDLEY \& JUdY, 1971; CAMP et al., 1977; OlsEN et al., 1978). Thus, the reproductive pattern of $A$. spinimanus in Macaé (ANDRADE et al., 2017) represents a physiologic adjustment to local conditions. According to the authors, although Macaé is less than $500 \mathrm{~km}$ distant from Ubatuba, it belongs to a resurgence area and has colder waters, similar to regions at higher latitudes where the reproduction is also seasonal (ANDRADE et al., 2017). We can infer that the reproductive pattern of $A$. spinimanus is related to the latitude, since in the present study the individuals showed a continuous reproduction, however this may be variable depending on the location i.e., their metabolism responds differently depending on the region, affecting the reproductive characteristics. Similarly, PinHeIro \& Fransozo (2002) and ANDRADE et al. (2015b) observed that an A. cribarius population adjusted to new environmental conditions and changed from a continuous to a seasonal reproduction to ensure a better nutrient supply to its larvae.

We found an association between abundance peaks of ovigerous females and low bottom temperatures, which were recorded in spring due to the SACW intrusion. The SACW has physical and chemical features that bring a nutrient enrichment to the coast, favoring the primary production (CASTRO-FILHO et al., 1987) and providing food supply to larvae (VEGA-PÉREZ, 1993). Therefore, SACW's physico-chemical features are probably the real modulators of $A$. spinimanus reproductive period in our study region. Other authors also suggested that the number of ovigerous females increases in periods of higher primary productivity (Gonçalves et al., 2017). According to these authors, this increase in periods of high phytoplankton levels is consistent with the patterns seen in crustaceans with planktotrophic larval stages. Since the phytoplankton form the base of marine food webs, serving as a food resource to several species with larval stages, their presence triggers several stimuli to the beginning of larval incubation (STARR et al., 1994). However, it must be highlighted that the reproductive period of tropical species with continuous reproduction cannot be established based on one or few parameters, but on a complex group of variables. These variables may include physical and chemical parameters and interactions, such as competition, predation, and social structures.

Based on our results, A. spinimanus showed the continuous spawning pattern proposed by CROCOS \& VAN DER VELDE (1995). The continuous reproduction allowed the establishment of juveniles year-round, and the recruitment was higher in periods following higher spawning rates. Moreover, juveniles were more abundant in periods with high organic matter contents. Although swimming crabs pray on bivalves and gastropods, they also consume decomposed organic matter (WARNER, 1977).

We can infer that the dynamics of water masses and biological interactions within the benthic community are the possible modulators of the reproductive strategies of A. spinimanus. Some of the population features observed during our 2-year survey indicate that $A$. spinimanus uses the Ubatuba region to complete its life cycle. These features include: the continuous reproduction, the high abundance of immature individuals and ovigerous females, and the presence of individuals at all stages of gonadal development. Therefore, direct and indirect changes in the region must be monitored to avoid damaging the natural stocks of marine organisms, and especially of A. spinimanus, which is becoming a new target species. In addition, this study provides a basis for comparison with current data, and it also attests the efficiency of the implemented strategies in 2008-2009 for the species conservation.

Acknowledgements. We thank NEBECC co-workers for their help during the fieldwork and Dr. Maria Lucia Negreiros-Fransozo for her constructive comments and valuable grammar review of this manuscript. The animals were collected within the guidelines of the ICMBio - Instituto Chico Mendes de Conservação da Biodiversidade - Ministério do Meio Ambiente (Permit $n^{\circ} 44329715$ ). The work was supported by the São Paulo Research Foundation (FAPESP) (grant numbers 94/4878-8, 97/12108-6, 97/12106-3, 97/ 12107-0 and 98/3134-6). 


\section{REFERENCES}

ABELLó, P. 1989. Reproduction and moulting in Liocarcinus depurator (Linnaeus, 1758) (Brachyura: Portunidae) in the northwestern Mediterranean Sea. Scientia Marina 53(1):127-134.

AB'SABER, A. N. 1955. Contribuição à geomorfologia do litoral paulista. Revista Brasileira de Geografia 18(1):3-48.

Andrade, L. S.; Antunes, M.; Lima, P. A.; Furlan, M.; Frameschi, I. F. \& Fransozo, A. 2015a. Reproductive features of the swimming crab Callinectes danae (Crustacea, Portunoidea) on the subtropical coast of Brazil: a sampling outside the estuary. Brazilian Journal of Biology 75(3):692-702

Andrade, L. S.; Bertini, G.; Fransozo, V.; Teixeira, G. M.; BarrosAlves, S. P. \& Fransozo A. 2014. Differential occupation of habitat as a reproductive strategy of the blue crab Callinectes ornatus Ordway, 1968 (Crustacea: Decapoda). Marine Biodiversity 44:27-36.

Andrade, L. S.; Costa, R. C. D.; Castilho, A. L.; Frameschi, I. F.; SancinetTI, G. S. \& Fransozo, A. 2017. Reproductive and population traits of the swimming crab Achelous spinimanus (Crustacea: Decapoda) in an upwelling region in southeastern Brazil. Nauplius 25:e2017004.

Andrade, L. S.; Fransozo, V.; Bertini, G.; Negreiros-Fransozo, M. L. \& LóPEZ-GreCo, L. S. 2015b. Reproductive plasticity in the speckled crab Arenaeus cribrarius (Decapoda, Brachyura, Portunidae) associated with a population decline. Journal of Coastal Research 31(3):645-652.

Barreto, A. V.; Batista-Leite, L. M. A. \& Aguiar, M. C. A. 2006. Maturidade sexual das fêmeas de Callinectes danae (Crustacea, Decapoda, Portunidae), nos estuários dos rios Botafogo e Carrapicho, Itamaracá, PE, Brasil. Iheringia, Série Zoologia 96(2):141-146.

BAUER, R. T. 1992. Testing generalizations about latitudinal variation in reproduction and recruitment with sicyonid and caridean shrimp species. Invertebrate Reproduction and Development 22:193-202.

Bernardes, V. P.; Martins, F. K.; Rodrigues, G. F. B.; Bernardo, C. H.; Sousa, A. N.; Bertini, G. \& Fransozo, A. 2019. The different depths gradients may affect the reproductive dynamics of Hepatus pudibundus (Herbst, 1785) (Decapoda: Aethridae) in the southeastern region of Brazil. Biologia:1-9.

Branco, J. O.; Lunardon-Branco, M. J. \& Souto, F. X. 2002. Estrutura populacional de Portunus spinimanus Latreille, 1819 (Crustacea, Portunidae) na Armação do Itapocoroy, Penha, Santa Catarina, Brasil. Revista Brasileira de Zoologia 19(3):731-738.

CAmp, D. K.; Whiting, N. H. \& Martin, R. E. 1977. Nearshore Marine Ecology at Hutchinson Island, Florida: 1971-1974. Florida Marine Research Publications 25:1-63.

Castro-Filho, B. M.; Miranda, L. B. \& Myao, S. Y. 1987. Condições hidrográficas na plataforma continental ao largo de Ubatuba: variações sazonais e em média escala. Boletim do Instituto Oceanográfico 35(2):135-151.

ChOY, S. C. 1988. Reproductive biology of Liocarcinus puber and L. holsatus (Decapoda, Brachyura, Portunidae) from the Grower Peninsula, South Wales. Marine Ecology 9(3):227-291.

Совo, V. J. \& Fransozo, A. 2003. External factors determining breeding season in the red mangrove crab Goniopsis cruentata (Latreille) (Crustacea, Brachyura, Grapsidae) on the São Paulo State northern coast, Brazil. Revista Brasileira de Zoologia 20(2):213-217.

Crocos, P. J. \& VAN DeR Velde, T. D. 1995. Seasonal, spatial and interanual variability in the reproductive dynamics of the grooved tiger prawn Penaeus semisulcatus in Albatross bay, Gulf of Carpentaria, Australia: the concept of effective spawning. Marine Biology 122:557-570.

De-Carli, B. P.; Severino-Rodrigues, E.; Rotundo, M. M.; MusielloFernandes, J. \& AnCona, M. C. 2016. Fecundidade e morfometria de Achelous spinimanus (Latreille, 1819) (Brachyura, Portunidae) capturado no litoral do estado de São Paulo, Brasil. Boletim do Instituto de Pesca 40(4):487-495.

D'Incao, F. H.; Valentini, E. L. F. \& Rodrigues, L. F. 2002. Avaliação da pesca de camarões nas regiões Sudeste e Sul do Brasil. Atlântica 24:103-116.

DudLEY, D. L. \& Judy, M. H. 1971. Occurrence of larval, juvenile, and mature crabs in the vicinity of Beaufort Inlet, North Carolina. National Oceanic and Atmospheric Administration, National Marine Fisheries Service 637:1-10.
FAO-Globefish. 2007. Crab commodity update. Copenhagen, GLOBEFISH databank.

Fransozo, A.; Negreiros-Fransozo, M. L.; Mantelatto, F. L. M.; Pinheiro, M. A. A. \& SAntos, S. 1992. Composição e distribuição dos Brachyura (Crustacea: Decapoda) do substrato não consolidado na Enseada da Fortaleza, Ubatuba - SP. Revista Brasileira de Biologia 52(4):667-675.

Fransozo, A.; Sousa, A. N.; Rodrigues, G. F. B.; Telles, J. N.; Fransozo, V. \& Negreiros-Fransozo, M. L. 2016. Crustáceos decápodes capturados na pesca do camarão-sete-barbas no sublitoral não consolidado do litoral norte do estado de São Paulo, Brasil. Boletim do Instituto de Pesca 42(2):369-386.

GIESE, A. C. 1959. Comparative physiology: annual reproductive cycles of marine invertebrates. Annual Review of Physiology 21:547-576.

Gonçalves, G. R. L.; Grabowski, R. C.; Bochini, G. L.; Costa, R. C. \& CASTILHO, A. L. 2017. Ecology of the spider crab Libinia ferreirae (Brachyura: Majoidea): ontogenetic shifts in habitat use. Hydrobiologia 795(1):313-325.

HeIRI, O.; LotTer, A. F. \& LemCKE, G. 2001. Loss on ignition as a method for estimating organic and carbonate content in sediments: reproducibility and comparability of results. Journal of Paleolimnology 25(1):101-110.

Kaiser, M. J.; Collie, J. S.; Hall, S. J.; Jennings, S. \& Poiner, I. R. 2002. Modification of marine habitats by trawling activities: prognosis and solutions. Fish and Fisheries 3:114-136.

LANCASTER, I. 1990. Reproduction and life history strategy of the hermit crab Pagurus bernhardus. Journal of the Marine Biological Association of the United Kingdom 70(1):129-142.

LeIFSSON, B. R. 1998. Life cycle, breeding periods and vertical distribution of Idotea granulosa Rathke and I. pelagica Leach (Crustacea: Isopoda) on Icelandic shores. Sarsia 83:1-13.

Lima, P. A.; Bertini, G.; Fransozo, V.; Gregati, R. A.; Corrêa FernandesGóEs, L. \& CASTILHO, A. L. 2014. Reproductive biology of Hepatus pudibundus (Crustacea: Brachyura), the most abundant crab on the southeastern Brazilian coast. Biologia 69(2):219-227.

Melo, G. A. S. 1996. Manual de Identificação dos Brachyura (caranguejos e siris) do Litoral Brasileiro. São Paulo, Plêiade, FAPESP. 604p.

Morritt, D. \& Stevenson, T. D. I. 1993. Factors influencing breeding initiation in the beachflea Orchestia gammarellus (Pallas) (Crustacea: Amphipoda). Journal of Experimental Marine Biology and Ecology 165:191-208

Negreiros-Fransozo, M. L.; Fransozo, A.; Pinheiro, M. A. A.; Mantelatto, F. L. M. \& Santos, S. 1991. Caracterização física e química da Enseada da Fortaleza, Ubatuba - SP. Revista Brasileira de Geociências 21(2):114-120.

Nenadic, O. \& Greenacre, M. J. 2007. Correspondence analysis in R, with two- and three-dimensional graphics: the ca package. Journal of Statistical Software 20:1-13.

OKsanen, J.; Blanchet, F. G.; Kindt, R.; Legendre, P.; Minchin, P. R.; O'hara, R. B.; Simpson, G. L.; Solymos, P.; Henry, M.; Stevens, H. \& Wagner, H. 2013. Vegan: Community Ecology Package. R package version 2:0-7.

Olsen, D. A.; Dammann, A. E. \& La Place, J. A. 1978. Portunus spinimanus Latreille, 1819 a portunid crab with resource potential in the U.S. Virgin Islands. Marine Fisheries Review 40:12-14.

Pinheiro, M. A. A. \& Fransozo, A. 2002. Reproduction of the speckled swimming crab Arenaeus cribrarius (Brachyura: Portunidae) on the Brazilian coast. Journal Crustacean Biology 22(2):416-428.

PIRES, A. M. S. 1992. Structure and dynamics of benthic megafauna on the continental shelf offshore of Ubatuba, southeastern, Brazil. Marine Ecology Progress Series 86:63-76.

R Development Core Team. 2013. R: A Language and Environment for Statistical Computing. Vienna, R Foundation for Statistical Computing. Available at $<$ http://www.R-project.org $>$.

Rakocinski, C. F.; LyCZKowsKi-ShULtZ, J. \& Richardson, S. L. 1996. Ichthyoplankton assemblage structure in Mississippi sound as revealed by canonical correspondence analysis. Estuarine, Coastal and Shelf Science 43:237-257.

Ripoli, L. V.; Fernandes, J. M.; Rosa, D. M. \& Araujo, C. C. V. 2007. Dinâmica populacional de Portunus spinimanus Latreille, 1819 (Crustacea, Portunidae) em um trecho litorâneo da Ilha do Frade, Vitória - ES. Boletim do Instituto de Pesca 33(2):205-212. 
Santos, S. \& Negreiros-Fransozo, M. L. 1997. Fecundity in Portunus spinimanus Latreille, 1819 (Crustacea, Brachyura, Portunidae) from Ubatuba, São Paulo, Brazil. Interciência 22(5):259-263.

Santos, S. \& Negreiros-Fransozo, M. L. 1999. Reproductive cycle of the swimming crab Portunus spinimanus Latreille (Crustacea, Brachyura, Portunidae) from Ubatuba, São Paulo, Brazil. Revista Brasileira de Zoologia 16(4): 1183-1193.

Santos, S.; Negreiros-Fransozo, M. L. \& Fransozo, A. 1995. Estructura poblacional de Portunus spinimanus Latreille, 1819 (Crustacea, Brachyura, Portunidae) en la Ensenada de la Fortaleza, Ubatuba (SP), Brasil. Revista de Investigaciones Marinas 16(3):37-43.

Severino-Rodrigues, E.; Pita, J. B. \& Graça-Lopes, R. 2018. Pesca artesanal de siris (Crustacea, Decapoda, Portunidae) na região estuarina de Santos e São Vicente (SP), Brasil. Boletim do Instituto de Pesca 27(1):7-19.

Silva, T. E.; Franzoso, V.; Taddei, F. G.; Costa, R. C.; Almeida, A. C. \& Fransozo, A. 2017. Reproductive analyses of the swimming crab Achelous spinicarpus (Stimpson, 1871) (Crustacea: Decapoda:
Portunoidea) on the northern coast of São Paulo, Brazil. Boletín del Instituto Oceanográfico de Venezuela 56(1):133-140.

Sousa, A. N.; Bertini, G.; Taddei, F. G.; Costa, R. C.; Silva, T. E. \& Fransozo, A. 2018. Modulating factors of the abundance and distribution of Achelous spinimanus (Latreille, 1819)(Decapoda, Portunoidea), a fishery resource, in Southeastern Brazil. PeerJ 6:e5720.

Starr, M.; Theriault, J. C.; Conan, G. Y.; Comeau, M. \& Robichaud, G. 1994. Larval release in a sub-euphotic zone invertebrate triggered by sinking phytoplankton particles. Journal Plankton Research 16:1137-1147.

Terossi, M.; Torati, L. S.; Miranda, I.; Scelzo, M. A. \& Mantelatto, F. L. 2010. Comparative reproductive biology of two southwestern Atlantic populations of the hermit crab Pagurus exilis (Crustacea: Anomura: Paguridae). Marine Ecology 31:584-591.

Vega-PÉREZ, L. A. 1993. Estudo do zooplâncton da região de Ubatuba, Estado de São Paulo. Boletim do Instituto Oceanográfico 10:65-84. WARNER, G. F. 1977. The biology of crabs. London, Eleck Science. 202p. 